\title{
Various dietary levels of protein and energy interaction on growth performance of white plumage japanese quails
}

\author{
Runjun Dowarah and A. P. S. Sethi \\ Department of Animal Nutrition, \\ College of Veterinary Science, Guru Angad Dev Veterinary and Animal Sciences University, Ludhiana, Punjab, India. \\ Corresponding author: Runjun Dowarah, email: runjundowarah03@gmail.com \\ APSS: apss Idh_pau@yahoo.com \\ Received: 31-03-2014, Revised: 07-05-2014, Accepted: 10-05-2014, Published online: 12-06-2014
}

doi: $10.14202 /$ vetworld.2014.398-402

How to cite this article: Dowarah R and Sethi APS (2014) Various dietary levels of protein and energy interaction on growth performance of white plumage japanese quails, Veterinary World 7(6): 398-402.

\begin{abstract}
Aim: The present study was investigated to determine the optimum energy and protein requirement for growth performance and nutrient digestibility of white plumage Japanese quail during starter (1 to 3 week) and finisher (4 to 5 week) phases.

Materials and Methods: Japanese quails were fed with nine diets consisting of three levels of energy (2600, 2800 and 3000; 2800, 2900 and $3000 \mathrm{Kcal} \mathrm{ME} / \mathrm{kg}$ ) and protein (23, 25 and 27; 18, 20 and 22\% CP) during starter and finisher phases, respectively, in $3 \times 3$ factorial design.

Results: Protein and energy individually had no influence on final body weight (FBW) and weight gain, while feed efficiency was significantly $(\mathrm{P} \leq 0.05)$ increased. The protein $\times$ energy interaction had significant $(\mathrm{P} \leq 0.05)$ effect on growth and nutrient utilization during both starter and finisher phases.

Conclusion: The growth performance was higher $(\mathrm{P} \leq 0.05)$ in quails fed on high protein-high energy (HP- HE) combination $(27 \% \mathrm{CP}$ and $3000 \mathrm{Kcal} \mathrm{ME} / \mathrm{kg}$ ) and medium protein-high energy (MP-HE) combination (20\% CP and $3000 \mathrm{Kcal} \mathrm{ME} / \mathrm{kg})$ during starter and finisher phase, respectively in autumn season. The diet with $20 \% \mathrm{CP}$ and $3000 \mathrm{Kcal} \mathrm{ME} / \mathrm{kg}$ significantly $(\mathrm{P} \leq 0.05)$ increased nutrients digestibility and major minerals $(\mathrm{Ca} \& \mathrm{P})$ balance.
\end{abstract}

Key words: energy, protein, white japanese quail.

\section{Introduction}

Japanese quail (Coturnix coturnix japonica) is recognized as a diversified poultry species augmenting for commercial meat and egg production [1]. The quail meat and egg are preferred over other species due to its better nutritional and medicinal value. Quail meat is delicious and tender with unique taste having mouthwatering delicacy. Importance of quail production increased day-to-day due to its early sexual maturity, rapid growth rate, short generation interval and smaller body size, which results in lower space and feed requirement.

NRC [2] recommended 24\% CP and $2900 \mathrm{kcal}$ $\mathrm{ME} / \mathrm{kg}$ for growing Japanese quails. Quails fed on diets with 27 and 24\% CP at constant level of energy (2800 Kcal ME/kg) during starter and grower phases had more body weight (BW) at 5 weeks of age compared to diet with 20\% CP [3]. Hyankova et al [4] also reported that Japanese quail fed on diets with 26 and $21 \% \mathrm{CP}$ had performed well during 1-21 days and 22-35 days of age. Higher feed conversion and growth rate were obtained by feeding 23.23\% CP with 12.97 MJ ME/kg during 0-5 weeks of age [5]. During the recent years, the meat production performance of Japanese quail was improved by genetic selection. The white strain of

Copyright: The authors. This article is an open access article licensed under the terms of the Creative Commons Attribution License (http://creativecommons.org/licenses/by/2.0) which permits unrestricted use, distribution and reproduction in any medium, provided the work is properly cited. quail was developed by Guru Angad Dev veterinary and Animal Science University (GADVASU), Ludhiana, India under the name "Punjab white quail".

Therefore, this necessary to evaluate the optimum requirement of energy and protein for growth performance and nutrient digestibility with improved genetic makeup to exploit production potentiality of meat type quails.

\section{Materials and Methods}

Ethical approval: This research work has been carried out with the approval of the institutional ethics committee and as per the laws in force at the time of carrying out this work and at the time of sending this paper for publication.

Experimental design: A total of 350 day old chicks were reared under battery brooder up to one weeks of age by feeding standard (27\% CP with $2900 \mathrm{ME}$ $\mathrm{Kcal} / \mathrm{kg}$ ) chick ration. Chicks were wing banded for identification on $5^{\text {th }}$ day. On $7^{\text {th }}$ day, chicks were weighed individually and distributed randomly into 9 groups having three replicates of 10 in each, after discarding too light and too heavy chicks. The birds were reared on 3-tier colony cages until 5 weeks of age. Proper ventilation and light were provided throughout the day. Fresh feed and clean water were offered ad libitum throughout the experimental period. The whole study was conducted during autumn season. The individual body weight and feed intake per replicate 
Table-1: Percent composition of experimental starter (1-3 weeks) and finisher (4-5 weeks) rations

\begin{tabular}{|c|c|c|c|c|c|c|c|c|c|c|c|c|c|c|c|c|c|c|}
\hline \multirow{3}{*}{$\begin{array}{l}\text { CP (\%) } \\
\text { ME (Kcal/kg) }\end{array}$} & \multicolumn{9}{|c|}{ Starter phase } & \multicolumn{9}{|c|}{ Finisher phase } \\
\hline & \multicolumn{3}{|c|}{23} & \multicolumn{3}{|c|}{25} & \multicolumn{3}{|c|}{27} & \multicolumn{3}{|c|}{18} & \multicolumn{3}{|c|}{20} & \multicolumn{3}{|c|}{22} \\
\hline & 2600 & 2800 & 3000 & 2600 & 2800 & 3000 & 2600 & 2800 & 3000 & 2800 & 2900 & 3000 & 2800 & 2900 & 3000 & 2800 & 2900 & 3000 \\
\hline \multicolumn{19}{|l|}{ Ingredients } \\
\hline Maize & 43 & 56.5 & 51 & 41.5 & 48 & 44 & 41 & 42 & 36.5 & 61.5 & 60 & 63 & 61 & 64 & 61.5 & 59.5 & 56.76 & 54 \\
\hline Soybean meal & 36 & 39 & 40 & 42 & 45 & 46 & 49 & 51 & 52 & 23 & 24 & 25 & 30 & 31 & 31.4 & 36.5 & 37.0 & 37.5 \\
\hline DORP & 17 & - & - & 12.5 & 1.0 & - & 6.0 & - & - & 11.5 & 10 & 5.0 & 5.0 & - & - & - & - & - \\
\hline Vegetable oil & - & 0.5 & 5.0 & - & 2.0 & 6.0 & - & 3 & 7.5 & - & 2.0 & 3.0 & - & 1.0 & 3.1 & - & 2.25 & 4.5 \\
\hline DCP & 2.0 & 2.0 & 2.0 & 2.0 & 2.0 & 2.0 & 2.0 & 2.0 & 2.0 & 2.0 & 2.0 & 2.0 & 2.0 & 2.0 & 2.0 & 2.0 & 2.0 & 2.0 \\
\hline LSP & 1.5 & 1.5 & 1.5 & 1.5 & 1.5 & 1.5 & 1.5 & 1.5 & 1.5 & 1.5 & 1.5 & 1.5 & 1.5 & 1.5 & 1.5 & 1.5 & 1.5 & 1.5 \\
\hline Additives* & + & + & + & + & + & + & + & + & + & + & + & + & + & + & + & + & + & + \\
\hline Crude protein & 22.8 & 23.2 & 23.2 & 24.7 & 25.2 & 24.9 & 26.7 & 27.1 & 27.1 & 17.7 & 17.9 & 18.1 & 19.7 & 19.8 & 19.8 & 22.0 & 22.0 & 21.8 \\
\hline Ether extract & 2.93 & 3.85 & 7.03 & 3.10 & 4.60 & 8.00 & 3.28 & 6.43 & 9.20 & 2.95 & 5.05 & 5.70 & 2.80 & 4.23 & 5.63 & 2.83 & 5.30 & 6.80 \\
\hline Crude fibre & 7.40 & 6.50 & 5.95 & 6.11 & 5.97 & 5.35 & 6.30 & 6.15 & 6.00 & 6.70 & 6.60 & 6.50 & 6.65 & 5.45 & 5.65 & 5.70 & 5.70 & 5.50 \\
\hline Organic matter & 92.1 & 93.9 & 93.9 & 92.6 & 93.2 & 93.4 & 92.8 & 92.9 & 92.9 & 94.2 & 93.5 & 93.4 & 92.3 & 94.6 & 94.8 & 94.3 & 94.6 & 93.4 \\
\hline Calcium & 1.17 & 1.06 & 1.08 & 1.16 & 1.06 & 1.17 & 1.16 & 1.17 & 1.15 & 1.00 & 1.04 & 1.06 & 1.03 & 1.03 & 1.01 & 1.01 & 1.00 & 1.02 \\
\hline Av. phosphorus & 0.50 & 0.50 & 0.50 & 0.51 & 0.50 & 0.50 & 0.51 & 0.52 & 0.52 & 0.46 & 0.46 & 0.46 & 0.47 & 0.47 & 0.46 & 0.47 & 0.47 & 0.47 \\
\hline
\end{tabular}

*Each 100 kg Ration contained: Salt 300g; Vitamin A 8,25,000 IU; Vitamin D3 1,20,000 IU; Vitamin K 100 mg; Riboflavin 500 mg; Thiamine 80 mg; Pyridoxine 160 mg; Cyanocobalamine 800 mg; Niacin 1200 mg; Calcium panthothenate 800 mg; Manganese Sulphate $23 \mathrm{~g}$; Magnesium Sulphate 50 g; Ferrous Sulphate 10 g; Copper Sulphate 500 mg; Potassium iodide 100 mg.

were recorded at weekly intervals.

The dietary treatments comprise of three levels of energy (2600, 2800 and 3000; 2800, 2900 and 3000 Kcal ME/kg) and protein (23, 25 and 27; 18, 20 and $22 \% \mathrm{CP}$ ) during starter (1-3 weeks) and finisher (4-5 weeks) phases, respectively. The ingredient and chemical composition of experimental dietsduring both the phases are given in Table-1.

Metabolic trial: After 5 week of experimental period, four birds from each replicate with comparable body weight were selected after discarding too light and too heavy chicks. Trial was conducted for six consecutive days including three days of preliminary feeding [5]. The residual feed was collected on the $4^{\text {th }}$ day and weighed to record the actual consumption of feed for each group. Total faeces voided by each group were collected after the end of the experiment and weighed. The faeces were mixed with $25 \mathrm{ml} \mathrm{10 \%}$ sulphuric acid and dried separately at $60^{\circ} \mathrm{C}$ in hot air oven. Feed offered, residual feed and dried faeces were ground and analysed for various proximate constituents, phosphorus [6] and calcium [7].

Statistical analysis: The data generated in present study subjected to appropriate statistical analysis using $17^{\text {th }}$ version of SPSS [8] and comparison of means was tested as per ANOVA [9] using Duncan's multiple range tests [10].

\section{Results}

Chemical composition of experimental rations: The CP percentage of low protein (LP), medium protein (MP) and high protein (HP) diets during starter and finishing phases were 22.80 to $23.20,24.70$ to 25.20 and 26.70 to $27.10 \% \mathrm{CP} ; 17.90$ to $18.10,19.70$ to 19.80 and 21.80 to $22.0 \% \mathrm{CP}$, respectively. Inclusion of vegetable oil to meet the high energy requirement within each CP level increased the ether extract levels in the diet of that particular ration.

The effects of different levels of dietary energy and protein during starter and finisher phases on growth rate, feed efficiency and nutrient utilization of white plumage Japanese quails are presented in Table2 and 3 .

Effect of protein: Protein as a variable singly had no significant $(\mathrm{P} \geq 0.05)$ effect on final body weight (FBW), weight gain during starter and finisher phases (Table-2). At the age of $3^{\text {rd }}$ week daily feed intake/bird, feed conversion efficiency (FCR) and calorie conversion ratio $(\mathrm{CCR})$ was significantly $(\mathrm{P} \leq 0.05)$ higher in quails of HP and MP fed groups. While, daily feed intake/bird and FCR were not influenced with increase of level of protein during 3-5 weeks of feeding. The weight gain per unit protein consumed did not differ significantly $(\mathrm{P} \geq 0.05)$ amongst the various protein levels studied during starter phase, while during finisher phase the protein efficiency ratio (PER) and CCR were significantly $(\mathrm{P} \leq 0.05)$ lower in quails fed on $\operatorname{HP}(22 \% \mathrm{CP})$ diets.

Non-significant $(\mathrm{P} \geq 0.05)$ difference was observed in digestibility of dry matter (DM), ether extract (EE), N- retention and calcium balance amongst three levels of protein. Although, crude fibre $(\mathrm{CF})$ digestibility was significantly $(\mathrm{P} \geq 0.05)$ highest in LP and MP fed groups. Whereas, available phosphorus balance was best $(\mathrm{P} \leq 0.05)$ observed with MP supplementation.

Effect of energy: The perusal of data indicated that there was no significant $(\mathrm{P} \geq 0.05)$ difference between the three levels energy irrespective of protein level on FBW and weight gain during starter phase. However, during finisher phase, highest $(\mathrm{P} \leq 0.05) \mathrm{FBW}$ and weight gain were observed in high energy (HE) fed group. The daily feed intake/bird decreased linearly $(P \leq 0.05)$ with increase of energy concentration in the diets. In the group fed HE, FCR and PER were significantly higher $(\mathrm{P} \leq 0.05)$ while $\mathrm{CCR}$ remain the same during the entire study.

Highest $(\mathrm{P} \leq 0.05) \mathrm{DM}$ digestibility, N-retention 
Table-2: Growth performance at different levels of protein and energy during starter and finisher phase.

\begin{tabular}{|c|c|c|c|c|c|c|c|c|c|c|c|c|}
\hline \multirow[t]{2}{*}{ Treatments } & \multicolumn{2}{|c|}{ Final body wt. (g) } & \multicolumn{2}{|c|}{ Gain in wt. (g) } & \multicolumn{2}{|c|}{$\begin{array}{l}\text { Feed intake/ } \\
\text { bird/day (g) }\end{array}$} & \multicolumn{2}{|c|}{ F.C.R } & \multicolumn{2}{|c|}{ P.E.R } & \multicolumn{2}{|c|}{ C.C.R } \\
\hline & $1-3$ & $4-5$ & $1-3$ & $4-5$ & $1-3$ & $4-5$ & $1-3$ & $4-5$ & $1-3$ & $4-5$ & $1-3$ & $4-5$ \\
\hline \multicolumn{13}{|c|}{ Effect of Protein } \\
\hline$L P^{*}$ & 159.8 & 244.6 & 123.5 & 84.8 & $21.7^{b}$ & 30.9 & $2.45 b$ & 5.12 & 1.78 & $1.09^{b}$ & $6.86^{\mathrm{b}}$ & $15.3^{b}$ \\
\hline MP & 159.9 & 247.8 & 123.7 & 87.9 & $19.9^{\mathrm{ab}}$ & 30.0 & $2.26^{a b}$ & 4.82 & 1.78 & $1.05^{b}$ & $6.31^{\mathrm{ab}}$ & $14.9^{\mathrm{ab}}$ \\
\hline $\begin{array}{l}\text { HP } \\
\text { S.E.M }\end{array}$ & $\begin{array}{l}161.7 \\
1.93\end{array}$ & $\begin{array}{l}247.7 \\
2.12\end{array}$ & $\begin{array}{l}126.0 \\
1.88\end{array}$ & $\begin{array}{l}86.0 \\
1.85\end{array}$ & $\begin{array}{l}19.3^{a} \\
0.30\end{array}$ & $\begin{array}{l}32.3 \\
0.88\end{array}$ & $\begin{array}{l}2.16^{\mathrm{a}} \\
0.06\end{array}$ & $\begin{array}{l}5.28 \\
0.19\end{array}$ & $\begin{array}{l}1.75 \\
0.05\end{array}$ & $\begin{array}{l}0.88^{a} \\
0.03\end{array}$ & $\begin{array}{l}5.98^{\mathrm{a}} \\
0.17\end{array}$ & $\begin{array}{l}13.8^{a} \\
0.44\end{array}$ \\
\hline \multicolumn{13}{|c|}{ Effect of Energy } \\
\hline LE $^{*}$ & 160.7 & $246.1^{\mathrm{ab}}$ & 124.8 & $85.3^{a}$ & $21.4^{b}$ & $33.2^{\mathrm{b}}$ & $2.40^{b}$ & $5.00^{b}$ & $1.68^{\mathrm{a}}$ & $0.93^{\mathrm{a}}$ & 6.25 & 14.9 \\
\hline ME & 159.8 & $242.3^{\mathrm{a}}$ & 123.7 & $82.5^{\mathrm{a}}$ & $20.2^{\mathrm{b}}$ & $30.2^{\mathrm{a}}$ & $2.30^{\mathrm{b}}$ & $4.67^{\mathrm{ab}}$ & $1.75^{\mathrm{a}}$ & $0.99^{a}$ & 6.43 & 13.9 \\
\hline $\begin{array}{l}\text { HE } \\
\text { S.E.M }\end{array}$ & $\begin{array}{l}160.9 \\
1.95\end{array}$ & $\begin{array}{l}251.8^{b} \\
2.12\end{array}$ & $\begin{array}{l}124.8 \\
1.91\end{array}$ & $\begin{array}{l}90.9^{b} \\
1.84\end{array}$ & $\begin{array}{l}19.3^{a} \\
0.31\end{array}$ & $\begin{array}{l}29.7^{a} \\
0.88\end{array}$ & $\begin{array}{l}2.17^{\mathrm{a}} \\
0.06\end{array}$ & $\begin{array}{l}3.89^{a} \\
0.19\end{array}$ & $\begin{array}{l}1.88^{b} \\
0.04\end{array}$ & $\begin{array}{l}1.10^{b} \\
0.03\end{array}$ & $\begin{array}{l}6.46 \\
0.16\end{array}$ & $\begin{array}{l}15.2 \\
0.44\end{array}$ \\
\hline \multicolumn{13}{|c|}{ Effect of Protein $\times$ Energy } \\
\hline LP-LE & $164.5^{\mathrm{bc}}$ & $244.4^{\mathrm{abc}}$ & $128.5^{b c}$ & $79.9^{\mathrm{a}}$ & $23.5^{\mathrm{d}}$ & $31.7^{\mathrm{ab}}$ & $2.56 \mathrm{~d}$ & $5.00^{b}$ & $1.70^{\mathrm{ab}}$ & $1.01^{\mathrm{abc}}$ & $6.65^{\mathrm{bc}}$ & $15.7 \mathrm{~b}$ \\
\hline LP-ME & $155.3^{\mathrm{ab}}$ & $237.0^{\mathrm{a}}$ & $119.1^{\mathrm{a}}$ & $81.7^{\mathrm{ab}}$ & $21.0 \mathrm{c}$ & $29.2^{\mathrm{a}}$ & $2.47^{\mathrm{cd}}$ & $4.67^{a b}$ & $1.76^{\mathrm{abc}}$ & $1.12^{b c}$ & $6.91^{\mathrm{c}}$ & $14.5^{\mathrm{ab}}$ \\
\hline LP-HE & $159.7^{\mathrm{abc}}$ & $252.4^{\mathrm{c}}$ & $123.0^{\mathrm{abc}}$ & $92.7 \mathrm{c}$ & $20.5 c$ & $31.8^{\mathrm{ab}}$ & $2.34^{\mathrm{bcd}}$ & $4.33^{a b}$ & $1.86^{\mathrm{bc}}$ & $1.16^{\mathrm{c}}$ & $7.02^{c}$ & $14.5^{\mathrm{ab}}$ \\
\hline MP-LE & $162.5^{\mathrm{abc}}$ & $252.6^{\mathrm{c}}$ & $126.1^{\mathrm{abc}}$ & $90.1^{\mathrm{bc}}$ & $20.6^{c}$ & $32.9^{\mathrm{ab}}$ & $2.30^{\mathrm{bc}}$ & $4.67^{\mathrm{ab}}$ & $1.74^{\mathrm{abc}}$ & $0.97^{\mathrm{abcc}}$ & $5.98^{\mathrm{ab}}$ & $14.5^{\mathrm{ab}}$ \\
\hline MP-ME & $160.3^{\mathrm{abc}}$ & $239.8^{a}$ & $124.0^{\mathrm{abc}}$ & $79.5 a$ & $20.5^{\mathrm{c}}$ & $28.7^{\mathrm{a}}$ & $2.32^{\mathrm{bcd}}$ & $4.33^{\mathrm{ab}}$ & $1.72^{\mathrm{abc}}$ & $0.99^{\mathrm{abc}}$ & $6.49^{\mathrm{abc}}$ & $14.7^{\mathrm{ab}}$ \\
\hline MP-HE & $156.8^{\mathrm{abc}}$ & $250.9^{c}$ & $121.0^{\mathrm{ab}}$ & $94.1^{c}$ & $18.6^{a}$ & $28.3^{\mathrm{a}}$ & $2.15^{\mathrm{ab}}$ & $3.33^{\mathrm{a}}$ & $1.86^{\mathrm{bc}}$ & $1.19^{c}$ & $6.45^{\mathrm{abc}}$ & $12.6^{a}$ \\
\hline HP-LE & $155.1^{\mathrm{a}}$ & $241.1^{\mathrm{ab}}$ & $119.7^{\mathrm{ab}}$ & $86.0^{\mathrm{abc}}$ & $20.1^{\mathrm{ab}}$ & $35.0^{\mathrm{b}}$ & $2.35^{\mathrm{bcd}}$ & $5.33^{b}$ & $1.58^{\mathrm{a}}$ & $0.81^{a}$ & $6.12^{\mathrm{ab}}$ & $16.0^{b}$ \\
\hline HP-ME & $163.8^{\mathrm{abc}}$ & $250.0^{c}$ & $127.8^{\mathrm{abc}}$ & $86.2^{\mathrm{abc}}$ & $19.2^{\mathrm{ab}}$ & $32.8^{a b}$ & $2.11^{\mathrm{ab}}$ & $5.00^{b}$ & $1.76^{\mathrm{abc}}$ & $0.86^{\mathrm{ab}}$ & $5.90^{\mathrm{a}}$ & $15.4^{b}$ \\
\hline $\begin{array}{l}\text { HP-HE } \\
\text { S.E.M }\end{array}$ & $\begin{array}{l}166.2^{c} \\
0.93\end{array}$ & $\begin{array}{l}252.0^{c} \\
0.96\end{array}$ & $\begin{array}{l}130.5^{\mathrm{C}} \\
0.91\end{array}$ & $\begin{array}{l}85.8^{\mathrm{abc}} \\
0.87\end{array}$ & $\begin{array}{l}18.7^{\mathrm{a}} \\
0.12\end{array}$ & $\begin{array}{l}29.1^{a} \\
0.48\end{array}$ & $\begin{array}{l}2.00^{\mathrm{a}} \\
0.03\end{array}$ & $\begin{array}{l}4.00^{\mathrm{ab}} \\
0.12\end{array}$ & $\begin{array}{l}1.91 \mathrm{c} \\
0.06\end{array}$ & $\begin{array}{l}0.96^{\mathrm{abc}} \\
0.05\end{array}$ & $\begin{array}{l}5.91^{\mathrm{a}} \\
0.07\end{array}$ & $\begin{array}{l}14.3^{\mathrm{ab}} \\
0.27\end{array}$ \\
\hline
\end{tabular}

Figures with different superscripts in each row differ significantly $(\mathrm{P} \leq 0.05)$ *LP-low protein, MP-medium protein, HPhigh protein * LE-low energy, ME-medium energy, HE-high energy.

Table-3: Percent nutrient utilization at different levels of protein and energy

\begin{tabular}{|c|c|c|c|c|c|c|}
\hline \multirow[t]{2}{*}{ Treatments } & \multirow[t]{2}{*}{$\mathrm{N}$-retention } & \multicolumn{3}{|c|}{ Digestibility (\%) } & \multicolumn{2}{|c|}{ Mineral retained (\%) } \\
\hline & & DM & EE & CF & Calcium & Av. Phosphorus \\
\hline \multicolumn{7}{|c|}{ Effect of Protein } \\
\hline LP & 44.6 & 86.4 & 87.7 & $42.6^{b}$ & 37.7 & $35.1^{\mathrm{a}}$ \\
\hline MP & 49.2 & 86.9 & 89.0 & $43.6^{b}$ & 39.3 & $44.2^{b}$ \\
\hline $\begin{array}{l}\text { HP } \\
\text { S.E.M } \\
\text { Effect of Ene }\end{array}$ & $\begin{array}{l}48.9 \\
2.04\end{array}$ & $\begin{array}{l}85.8 \\
1.15\end{array}$ & $\begin{array}{l}85.5 \\
1.11\end{array}$ & $\begin{array}{l}38.0^{\mathrm{a}} \\
2.31\end{array}$ & $\begin{array}{l}33.8 \\
2.68\end{array}$ & $\begin{array}{c}38.1^{\mathrm{ab}} \\
2.94\end{array}$ \\
\hline LE & $47.4^{\mathrm{ab}}$ & $86.3^{a b}$ & $84.6^{\mathrm{a}}$ & 40.0 & 35.2 & $36.7^{\mathrm{a}}$ \\
\hline ME & $42.5^{\mathrm{a}}$ & $83.8^{\mathrm{a}}$ & $88.6^{b}$ & 42.5 & 34.0 & $34.5^{\mathrm{a}}$ \\
\hline $\begin{array}{l}\text { HE } \\
\text { S.E.M } \\
\text { Effect of Pro }\end{array}$ & $\begin{array}{c}51.4^{b} \\
2.04 \\
\text { Energy }\end{array}$ & $\begin{array}{c}88.4^{b} \\
1.15\end{array}$ & $\begin{array}{c}89.3^{b} \\
1.11\end{array}$ & $\begin{array}{l}42.4 \\
2.32\end{array}$ & $\begin{array}{l}41.0 \\
2.68\end{array}$ & $\begin{array}{c}44.7^{\mathrm{b}} \\
2.94\end{array}$ \\
\hline LP-LE & $88.6^{\mathrm{bc}}$ & $47.1^{\mathrm{ab}}$ & $88.3^{b c}$ & $42.3^{b c}$ & $33.6^{\mathrm{ab}}$ & $33.2^{\mathrm{ab}}$ \\
\hline LP-ME & $82.5^{\mathrm{a}}$ & $42.3^{\mathrm{a}}$ & $86.2^{\mathrm{abc}}$ & $41.1^{\mathrm{abc}}$ & $38.3^{b c}$ & $30.6^{a}$ \\
\hline LP-HE & $88.2^{b c}$ & $44.5^{\mathrm{ab}}$ & $88.4^{\mathrm{bc}}$ & $44.5^{\mathrm{bc}}$ & $41.2^{b c}$ & $41.5^{\mathrm{ab}}$ \\
\hline MP-LE & $84.1^{\mathrm{ab}}$ & $44.1^{\mathrm{ab}}$ & $84.8^{\mathrm{ab}}$ & $42.5^{\mathrm{bc}}$ & $40.0^{b c}$ & $42.6^{b}$ \\
\hline MP-ME & $82.7^{\mathrm{a}}$ & $41.4^{\mathrm{a}}$ & $88.9^{\mathrm{bc}}$ & $43.0^{b c}$ & $26.3^{\mathrm{a}}$ & $33.8^{\mathrm{ab}}$ \\
\hline MP-HE & $92.5^{\mathrm{c}}$ & $59.5^{\mathrm{c}}$ & $92.7^{\mathrm{C}}$ & $45.8^{c}$ & $47.2^{b}$ & $52.7^{\mathrm{c}}$ \\
\hline HP-LE & $86.3^{\mathrm{ab}}$ & $50.9^{\mathrm{b}}$ & $80.6^{a}$ & $35.0^{\mathrm{a}}$ & $31.9^{\mathrm{ab}}$ & $34.2^{\mathrm{ab}}$ \\
\hline HP-ME & $87.0^{\mathrm{ab}}$ & $43.9^{\mathrm{ab}}$ & $91.1^{\mathrm{bc}}$ & $44.2^{\mathrm{bc}}$ & $35.3^{\mathrm{ab}}$ & $41.2^{\mathrm{ab}}$ \\
\hline $\begin{array}{l}\text { HP-HE } \\
\text { S.E.M }\end{array}$ & $\begin{array}{c}84.5^{\mathrm{ab}} \\
1.56\end{array}$ & $\begin{array}{c}50.2^{\mathrm{b}} \\
3.20\end{array}$ & $\begin{array}{c}86.8^{\mathrm{abc}} \\
1.52\end{array}$ & $\begin{array}{c}36.9^{\mathrm{ab}} \\
4.28\end{array}$ & $\begin{array}{c}34.7^{\mathrm{ab}} \\
4.59\end{array}$ & $\begin{array}{c}39.9^{\mathrm{ab}} \\
4.76\end{array}$ \\
\hline
\end{tabular}

Figures with different superscripts in each row differ significantly $(P \leq 0.05)$

and $\mathrm{P}$ balance were observed in quails fed on HE diets, while the $\mathrm{CF}$ digestibility and calcium balance were not influenced. Non-significant $(\mathrm{P} \geq 0.05)$ difference in EE digestibility was obtained between medium energy $(\mathrm{ME})$ and $\mathrm{HE}$ diets, which was significantly $(\mathrm{P} \leq 0.05)$ higher than low energy (LE) fed diet.

Protein $\times$ Energy interaction: The HP-HE combination yielded significantly $(\mathrm{P} \leq 0.05)$ higher FBW and weight gain during 1-3 weeks of age (Table-2). During finisher phase, significantly $(\mathrm{P} \leq 0.05)$ higher FBW was attained at all high protein and energy combination and of MPLE and LP-HE fed groups. Non-significant $(\mathrm{P} \geq 0.05)$ difference with respect to weight gain was obtained in the diet containing MP-HE and LP-HE fed groups 
which was significantly $(\mathrm{P}<0.05)$ higher than rest of treatments. Lowest $(\mathrm{P} \leq 0.05)$ daily feed intake/bird at $3^{\text {rd }}$ week of age was observed at HE supplemented diet in both with HP and MP fed groups. However, daily feed intake/bird was decreased with increase in energy level at all the levels of protein at $5^{\text {th }}$ week of age. Highest FBW, weight gain and lowest daily feed intake resulted in higher $(\mathrm{P} \leq 0.05) \mathrm{FCR}, \mathrm{PER}$ and $\mathrm{CCR}$ in the HP-HE and MP-HE supplemented diets during starter and finisher phase respectively.

MP-HE fed group exhibited significantly $(\mathrm{P} \leq 0.05)$ higher digestibility's of $\mathrm{DM}, \mathrm{EE}$, and $\mathrm{CF}, \mathrm{N}$ retention, calcium and available phosphorus balance.

\section{Discussion}

Improper level of energy leads to restriction of feed intake which also lower protein intake that might induce amino acid deficiencies causing negative effect on performance. Again protein has the highest heat increment amongst dietary nutrients, therefore, low protein diet recommended on heat stressed broilers [11]. Effect of different levels of protein and energy on growth performance and nutrient utilization were studied in broiler quails.

Effect of protein: Japanese quail required a dietary protein level of 26 to $27 \% \mathrm{CP}$ during initial phase of growth (5-27 days of age) for optimum weight gain and feed efficiency $[12,13]$. Similarly, Rajini and Narhari [14] also recommended that dietary protein level of $28 \%$ and $20 \%$ irrespective of energy level during starter and finisher phase had better $(\mathrm{P}<<0.05)$ growth rate and feed efficiency.The positive effect of higher dietary level of protein on growth performance of quail was obtained only up to starter phase $[15,16,17]$. FCR significantly $(\mathrm{P}<0.05)$ better at high protein level which remained statistically similar at medium $(22 \%$ $\mathrm{CP})$ and low $(20 \% \mathrm{CP})$ protein level during 0-28 days of age [18]. Whereas, non-significant differences were observed on gain in weight, feed intake and feed efficiency at different ( 23 and $25 \% \mathrm{CP}$ ) levels of protein at 5 weeks of age [19,20]. Karaalp et al. [21] also reported that PER decreased $(\mathrm{P}<0.05)$ with higher levels of crude protein in the $\operatorname{diet}(20-24 \% \mathrm{CP})$.

Effect of energy: The improvement of gain in weight and FCR at highest level of energy could be due to the use of fat to increase the energy level and the increment of digestibility of nutrients. With decrease of dietary energy the feed intake increases due to compensate energy intake [22]. Elangovan et al [23, 24] reported that body weight gain was significantly higher in the diet with 2900 and $2700 \mathrm{Kcal} \mathrm{ME} / \mathrm{kg}$ than $2500 \mathrm{Kcal}$ $\mathrm{ME} / \mathrm{kg}$ diet. While, CCR remained same at various level of energy during 4-7 weeks of age [25].

Protein $\times$ Energy interaction: An interaction existed in weight gain between energy and protein as least weight gain $(\mathrm{P}<0.05)$ observed in both ME (12.13 and 13.39) fed groups with low CP diet [26]. Significantly $(\mathrm{P}<0.01)$ higher gain in weight and better FCR was observed by supplementing highest level of protein and energy combination $(27 \% \mathrm{CP}$ with $3200 \mathrm{Kcal} \mathrm{ME} / \mathrm{kg})$ $[13,27]$. Whereas, Shrivastav et al. [28] recommended $27 \%$ crude protein and $2800 \mathrm{kcal} \mathrm{ME} / \mathrm{kg}$ for the quail up to 2 weeks of age and $24 \% \mathrm{CP}$ with the same energy level from 3 to 5 weeks of age in dry tropical climate. Better utilization of dietary protein with respect to energy intake results highest $(\mathrm{P}<0.01) \mathrm{N}$-retention at MP-HE was in agreement of results obtained by Kaur et al. [5] in quails fed different energy and protein or EAA combination. With increase of live weight gain might be increased mineral balance as most of the enzymes related to protein and energy metabolism are mineral dependent [29].

\section{Conclusion}

The results of the present study indicated that white plumage Japanese quails performed well at 27 and $20 \% \mathrm{CP}$ with $3000 \mathrm{Kcal} \mathrm{ME} / \mathrm{kg}$ diet during starter and finisher phase, respectively in autumn season. The digestibility of proximate constituents and major minerals ( $\mathrm{Ca}$ and $\mathrm{P}$ ) balance were higher at $20 \% \mathrm{CP}$ and $3000 \mathrm{Kcal} \mathrm{ME} / \mathrm{kg}$ during the finisher phase.

\section{Authors' contributions}

Both the authors contributed equally for conducting the experiment and preparation of manuscript. Both authors read and approved the final manuscript.

\section{Acknowledgements}

The authors are thankful to The, Vice chancellor of GADVASU, Ludhiana, Punjab, India for the financial support extended for this work.

\section{Competing interests}

The authors declare that they have no competing interests.

\section{References}

1. Sangilimadan, K., Asha Rajini, R., Prabakaran, R. and Murugan, M. (2012) Effect of dietary protein on layer Japanese quails (coturnix coturnix japonica) in tropics. Tamil Nadu J. Vet. Anim. Sci., 8 (5): 271-278.

2. NRC. (1994) Nutrient requirements of poultry. National Academy Press, Washington D.C. $9^{\text {th }}$ revised edition $\mathrm{p} 155$.

3. Shrivastav, A. K. and Johari, T. S. (1993) Evaluation of different feeding schedules during stating and growing periods in Japanese quail. Indian J. Poultry Sci., 28(3): 18389.

4. Hyankova, L., Dedkova, L., Knizetova, H. and Klecker, D. (1997) Response in growth, feed intake and food conversion efficiency to different dietary protein concentrations in meattype lines of Japanese quail. Br Poultry Sci., 38: 564-70.

5. Kaur, S., Mandal, A. B., Singh, K. B. and Kadam, M. M. (2008) The response of Japanese quails (heavy body weight line) to dietary energy levels and graded essential amino acid levels on growth performance and immuno-competence. Livest Sci., 117 (2/3): 255-62.

6. AOAC. (1990) Official method of analysis: $16^{\text {th }}$ ed. Association of official analytical chemists Washington D C, USA.

7. Talapatra, S. K., Ray, S. C. and Sen, K. C. (1940) The analysis of minerals constituents in biological materials. Indian J Vet Sci Anim Husb., 10: 243-47.

8. Snedecor, G. W. and Cochran, W. G. (1989) Statistical 
methods $8^{\text {th }}$ ed. Iowa State University Press, Amees, Iowa, USA.

9. SPSS version 17.0. (2010) Base Application Guide 7.5. Statistical Package for Social Science, USA7.

10. Duncan, D. B. (1995) Multiple range and multiple F-test. Biometrics II. 1-42.

11. Siyadati, S. A., Irani, M. and Ghavidel, Z. (2011) Effect of varying dietary energy to protein ratio on productive performance and carcass characteristics of Japanese quail. Ann Biol Res., 2(1): 149-55.

12. Oliveira, N. T. E., Silva, M. A., Soares, R. T.R.N., Fonseca, J. B., Thiebaut, J. T. L., Fridrich, A. B., Duarte, R. and Teixeira, G. L. V. (2002) Energy and protein requirements for male Japanese quails reared for meat production. Braz J Vet Med., 54(2): 196-203.

13. Kaur, S., Mandal, A. B., Singh, K. B. and Narayan, R. (2006) Optimising needs of essential amino acids in diets with or without fish meal of growing Japanese quails (heavy body weight line). J Sci Food Agr., 86: 320-327.

14. Rajini, R. A. and Narahari, D. (1998) Dietary energy and protein requirements of growing Japanese quails in the tropics. Indian J Anim Sci., 68(10): 1082-86.

15. Lepore, P.D. and Marks, H.L. (1971) Protein and energy requirements of lines selected under different nutritional environments. Poultry Sci.,50: 1335-1341.

16. Marks, H.L. (1971) Evaluation of growth selected quail lines under different nutritional environments. Poultry Sci., 50: 1753-1761.

17. Mosaad, G.M.M. and Iben, C. (2009) Effect of dietary energy and protein levels on growth performance, carcass yield and some blood constituents of Japanese quails (Coturnix coturnix Japonica). Die Bodenkultur., 64(4): 3946.

18. Gheisari, A., Halaji, H. A., Ghasen, M., Toghyani, M., Alibemani, A. and Saeid, S. E. (2011) Effect of different dietary levels of energy and protein on performance of Japanese quails. $2^{\text {nd }}$ International Conference on Agriculture and Animal Science, Singapore., 22: 156-59.

19. Senapati, P.K., Mondal, K.G., Das, K. and Chatterjee, A.K. (1996) Protein requirement of meat type Coturnix quail.
Environ Ecol., 14(3): 566-569.

20. Shrivastav, A. K. and Panda, B. (1991) Effect of reducing dietary protein during different finishing periods in quail broilers. Indian J Anim Sci., 61(2): 206-10.

21. Karaalp, M., Sezer, M. and Kilinc, K. (2009) The effect of various dietary crude proteins on growth and excreta nitrogen in Japanese quails. Indian Vet J., 86(4): 383-86.

22. Attia, Y.A., Aggoor, F.A.M., Ismail, F.S.A., Qota, E.M.A. and Shakmak, E.A. (2006) Effect of energy level, rice by products and enzyme addition on growth performance and energy utilization of Japanese quail. EPC 2006, XII European Poultry Conference, Verona, Italy, September 1014.

23. Elangovan, A. V., Mandal, A. B., Tyagi, P. K., Toppo, S. and Johri, T. S. (2004) Effects of enzymes in diets with varying energy levels on growth and egg production performance of Japanese quail. JSci Food Agr., 84 (15): 2028-34.

24. Bariha, S. K., Panda, N., Mishra, P. K., Pati, P. K. and Behera, P. C. (2010) Performance of Japanese quails under different energy and protein levels in hot and humid conditions. Indian J Poultry Sci., 45(3): 302-07.

25. Olubamiwa, O., Haruna, E. S., Musa, U., Akinwale, T. O., Lombin, L. H. and Longe, O. G. (1999) Effect of different energy levels of coca husk-based diets on productive performance of Japanese quails. Niger J Anim Prod., 26: 8892.

26. Wei, H. W., Hsieh, T. L., Chang, S. K., Chiu, W. Z., Huang, Y. C. and Lin, M. F. (2011) Estimating the requirement of dietary crude protein for growing blue-breasted quail. World Poultry Sci J.,5(10): 1506-14.

27. Gezen, S. S. and Petek, M. (2003) The effects of different energy and protein containing rations on Pharaoh quail performance. Veteriner Fakultesi Dergisi, Uludag Universitesi., 22(1/3): 57-63.

28. Shrivastav, A. K.andPanda, B. (1999) A review of quail nutrition research in India. World Poultry Sci., J 55 (1): 7381.

29. Kaur, S. and Mandal, A. B. (2009) Effect of dietary levels of protein and amino acids on utilization of certain minerals in growing Japanese quail. Indian J Poultry Sci., 44 (1): 59-63. 